\title{
Determination of Sambucus Interspecific Hybrid Structure using Molecular Markers
}

\author{
Metka ŠIŠKO, Anja IVANUŠ, Anton IVANČIČ \\ University of Maribor, Faculty of Agriculture and Life Sciences, Pivola 10, 2311 Hoče, Slovenia
}

\begin{abstract}
Phenotypic and genotypic variations within the genus Sambucus are limited. They could be efficiently increased by genetic recombination involving different species. The aim of the presented investigation was to assess the possibility of using molecular approach (i.e., microsattelites) in determination of unknown hybrid structures. The study involved 47 Sambucus genotypes (parental species and intespecific hybrids), and six microsatellite loci were analysed. The clustering method grouped the analysed genotypes into four main groups. The first main group involved two sub-groups: one with taxons and hybrids involving $S$. racemosa (in broad sense) and the other involving two botanical varieties of $S$. nigra. In the second main group, there was a sub-group involving hybrids between S. javanica and S. nigra, and a sub-group involving $\mathrm{F}_{1}$ hybrids between $S$. javanica and $S$. ebulus. The third main group contained a sub-group with hybrids between $S$. javanica and S. nigra 'Black Beauty', a sub-group with hybrids involving S. javanica, S. nigra and S. racemosa (miquelii), a sub-group with backcrosses $S$. javanica $\times($ S. javanica $\times$ S. ebulus $)$, and un unknown hybrid. The fourth main group included a subgroup with $\mathrm{F}_{1}$ hybrids $S$. javanica $\times S$. ebulus, a sub-group involving various taxons of $S$. racemosa (in broad sense), and a sub-group involving hybrids between S. cerulea and S. javanica, with and without $S$. nigra. Our study shows that molecular analysis can be helpful in determining some of the unknown but simple interspecific hybrids of Sambucus. In the cases of complex hybrid combinations, the use of SSRs is most probably not the best solution.
\end{abstract}

Key words: Sambucus, SSR markers, interspecific hybrids, clustering method, molecular markers

\section{INTRODUCTION}

Elderberries belong to the genus Sambucus and the family Adoxaceae (Bolli,1994). Since ancient times, they have been considered as very useful, especially as medicinal and food plants. The most valuable are their fruits and inflorescences, although useful substances can be found also in roots, bark, leaves and shoots (Shokrzadeh et al., 2009, Atkinson and Atkinson, 2002, Charlebois et al., 2010, Vlachojannis et al., 2010, Mikulič-Petkovšek et al., 2015a, Mikulič-Petkovšek et al., 2015b, Todorović et al., 2017). Elderberries can be found in almost all regions of the world, except deserts and extremely cold areas. They grow as small deciduous trees or shrubs of various shapes, or herbs characterised by pinnately compound leaves borne oppositely along stems, and flat to roundish clusters of small white-yellowish or sometimes pinkish-purple flowers and, during maturity, by small brownblack, blue, red, orange or yellow berries (Fernald, 1950, Bolli, 1994). The taxonomy of the genus Sambucus is highly sophisticated due to enormous phenotypical diversity and geographical distribution. The genus includes from less than 10 to more than 30 species, depending on the taxonomical approach. Von Schwerin (1920) recognised 28 species and several varieties. R. Bolli (1994), in his PhD dissertation, reduced the number of species to only nine: Sambucus ebulus L., S. wightiana Wall. ex Wight et Arnott, S. adnata DC., S. 
gaudichaudiana DC., S. australasica (Lindley) Fritsch, S. javanica Blume, S. nigra L., S. australis Cham. et Schlecht. and $S$. racemosa L. Several, previously independent species became subspecies or botanical varieties. Five taxa, formerly considered as distinct species (i.e., S. canadensis, S. cerulea, S. peruviana, S. maderensis and S. palmensis, are now being considered as subspecies within $S$. nigra. His reduction was most probably too drastic and probably needs several corrections (Applequist, 2015). Proper taxonomy is especially important for breeders conducting interspecific crosses.

Following the traditional taxonomy, the most important species are S. cerulea Raf. (blue elder), S. javanica (Javanese or Chinese elder), and S. nigra (common or black elder/ elderberry). All elderberries are characterised by extremely small flowers, forming relatively dense inflorescences. Due to small sizes of flowers (when they are ready for emasculation, they measure 1.8-2.2 $\mathrm{mm}$ in diameter), artificial hybridisation of elderberries is very difficult. The emasculation usually takes place late in the afternoon, one day before anthesis, or in early hours in the following morning, when the flowers are still closed. The breeder has to remove all (5) anthers, together with corolla, without damaging the pistil. The pollination usually takes place immediately after all selected flowers of an inflorescence have been emasculated and other flowers carefully removed. For pollination, one can use fresh or properly stored pollen. To promote faster germination of pollen, low concentrated sugary-water solutions can be used. The pollinated inflorescences have to be protected from uncontrolled pollination by semi-transparent bags, which are removed after approximately a week (Ivančič, personal experience).

Elderberry breeding is relatively new and most of the present cultivars are probably direct selections from locally grown populations, or hybrids between locally grown genotypes. To our knowledge, most of the breeders have been using intraspecific hybridisation in order to create genetic variation. Interspecific hybridization, so far, has been rarely used. The earliest systematic and documented attempts to produce hybrid plants were reported by Böcher (1941), Winge (1944), Chia (1975), Koncalová et al. (1983) and Nilsson (1987). The main problems were difficulties in hybridisation technique, low number of successful fertilisations and sterility among progenies. Higher level of fertility was achieved when using closely related species, e.g., S. nigra $\times$ S. canadensis, compared to the cross between $S$. nigra and S. ebulus.

The large scale elderberry breeding programme based on interspecific hybridisation, at the Faculty of Agriculture and Life Sciences, University of Maribor, Slovenia, began in 2003 by the lead author of this article. As elderberries, in Slovenia, are not considered to be important fruit bearing plants, the programme has never been officially funded. The first experimental crosses based on normal hand emasculation technique took place several years earlier. Those crosses were based on classical manual emasculation and resulted in a limited number of successful interspecific hybrids. In 2001, a self-incompatible genotype of $S$. javanica was introduced from the Island of Espiritu Santo, Vanuatu, and two years later, included in the hybridisation programme. Due to its almost complete self-incompatibility, emasculation of the female parent was not necessary.
Our hybridisation programme involved 5 crucial species (S. cerulea, S. javanica, S. ebulus, S. nigra, S. racemosa) and two botanical varieties (S. nigra L. var. laciniata L., S. nigra L. var. viridis Weston). S. racemosa was represented by various taxons which had been previously recognised as species, but in the revised taxonomy of Bolli (1994) they are all included to S. racemosa (i.e., S. koreana, S. miquelii, S. sibirica, S. tigranii). The two above mentioned botanical varieties are probably the oldest botanical varieties of elderberries documented in the literature. The scientific name of $S$. nigra subsp. nigra var. laciniata (parsley-leaved or cut-leaved variety) appeared for the first time in Species Plantarum (Linaeus, in 1753, vol.1, p. 270). Few years later, it was also mentioned by Richard Weston (1775), p. 39, who was also the author of the scientific name of the $S$. nigra subsp. nigra var. viridis. For this variety, he also used the common name 'green-berried elder tree'. Parsley-leaved genotypes were also described in other species (or subspecies), e.g., Sambucus canadensis L. var. laciniata A. Gray. They were also observed among our interspecific hybrids (Ivančič, personal observations).

The main objective of this programme was to recombine the most important positive morphological and physiological characteristics of S. cerulea, S. javanica, S. ebulus, S. nigra and $S$. racemosa. The final aim was to create dwarf or semidwarf, herbaceous or semi-herbaceous plants which would enable plantations with a higher density of plants, simple maintenance and mechanical harvest (Simonovik, 2007, Simonovik et al., 2007). S. ebulus was considered as a source of genes for dwarf herbaceous growth, while S. nigra and $S$. cerulea were representing the main genetic resources for productivity and desired chemical composition of fruits and inflorescences. Because of dwarf herbaceous growth harvesting would be easy and pruning would not be needed. At the beginning of each growth season, plants would be cut to the ground (mulched) and new stems would regrow from underground shoots.

S. javanica from Espiritu Santo, due to its tropic (or sub-tropic) origin, was mainly used as a source of selfincompatibility. Later, additional genotypes of this species were introduced from Africa, but they were not selfincompatible. New reports (e.g., Wenga et al., 2019), however, indicate that stem ethanol extracts of $S$. formosana Nakai (which is one of the synonyms of S. javanica) could be a valuable source of substances fighting human coronavirus NL63 (HCoV-NL63), one of the main circulating HCoVs worldwide, which causes difficulties in respiratory tract such as runny nose, cough, bronchiolitis and pneumonia.

The breeding programme at the Faculty of Agriculture and Life Sciences followed the scheme of modified phenotypic recurrent selection adapted to specific characteristics of different elderberry species. The programme was divided in cycles and each cycle consisted of three phases: (1) genetic recombination of selected genotypes, (2) morphological and chemical evaluation of the offspring individuals and (3) selection of superior individuals for new genetic recombinations (crosses) in order to obtain a new generation of hybrids, belonging to a new cycle. The number of hybrid combinations per cycle varied between 100 and 120, while the number of seeds per cycle generally exceeded 4,000 . The average germination rate was approximately $45 \%$ and 
individual cycles were completed within 4 to 6 years (Ivančič, unpublished).

Chemical analyses of the obtained interspecific hybrids and their parental species revealed tremendous variations of chemical composition and many of the hybrids were superior when compared to their parental species (MikuličPetkovšek et al., 2014, Mikulič-Petkovšek et al., 2015a, Mikulič-Petkovšek et al., 2015b, Mikulič-Petkovšek et al., 2016, Todorović et al., 2017, Imenšek et al., 2020). The first molecular evaluation of hybrids (i.e., hybrid origin) took place in 2006 and were published by Simonovik et al. (2007) and was based on the sequenced cpDNA region, genome size differences and PCR-RFLP analysis of the nrDNA ITS region.

At the beginning (in the first cycle), molecular evaluation of the interspecific structure was not necessary. The hybrids had several intermediate characteristics and used to be more winter hardy when compared to the tropical female parent $(S$. javanica). It was not difficult to see the differences in growth types, leaf shapes and inflorescences. The examples were the hybrids $S$. javanica $\times S$. ebulus, S. javanica $\times$ S. cerulea, $S$. javanica $\times S$. racemosa and $S$. javanica $\times S$. nigra. The difficulties, however, arose later when complex interspecific hybrids were formed. The hypothetical example can be: ((S. javanica $\times S$. cerulea $) \times(S$. javanica $\times S$. racemosa $)) \times((S$. cerulea $\times S$. nigra $) \times(S$. javanica $\times S$. nigra $)$. This complex hybrid involves 4 species and it is practically impossible to determine its hybrid structure using morphological traits. Following the comments published by Applequist (2015), we consider S. cerulea as an independent species.

The main objective of this paper was to check the possibility of using SSRs for determining the complex hybrid structure in various complex elderberry interspecific hybrids. We assumed that molecular markers could probably be very helpful for finding out which species were incorporated in an unknown, complex interspecific hybrid. The exact hybrid structure (i.e., in which way individual species were incorporated in the hybrid structure) most probably could not be defined.

\section{MATERIALS AND METHODS}

\section{Plant material (elderberry genotypes)}

The list of the species, varieties and interspecific hybrids is presented in Table 1. Samples of all analysed hybrids were collected in May 2016 from plants growing in the Plant Gene Bank of the Faculty of Agriculture and Life Sciences of the University of Maribor. Samples of the majority of parental species (i.e., S. cerulea, S. javanica, two genotypes of $S$. ebulus, two genotypes of S. nigra and S. racemosa including its taxons named as koreana, miquelii, sibirica, tigranii), however, were collected in SE Slovenia where the initial hybridisation had taken place. Almost all hybrid plants and some of the parental genotypes, originated directly from seed. The exceptions were two botanical varieties (S. nigra var. laciniata, S. nigra var. viridis) and ornamental cultivar 'Black Beauty' (BB)), all belonging to $S$. nigra. There was no clonal multiplication of hybrids; the only exception was JA $\times$ CER No3 which had been clonally propagated for experimental purposes. This hybrid was found to have several very useful and attractive traits such as medium height, high yield, large infructescences, stable wine-red colour of juice, better taste when compared to black elderberry, pleasant odour of inflorescences (different from other genotypes) and plants were less affected by aphids. The analysed hybrids originated from the first three cycles of crossings (first three cycles of the modified phenotypic recurrent selection). In each cycle, the selection of the parental material for the following series of crosses was based on plant vigour, growth characteristics, and fruit and floral characteristics (fruit size and colour, taste and chemical composition). Since the parental material used in interspecific crosses was assumed to be highly heterozygous, each offspring individual originating from the same cross most probably represented a different genotype. This means that two or more hybrids with the same hybrid structure (e.g., $\mathrm{JA} \times(\mathrm{JA} \times \mathrm{EB})$, Table 1$)$ should be considered as genetically different.

\section{Molecular analysis}

\section{DNA isolation}

DNA was extracted from fresh, young leaves using the CTAB protocol (Doyle and Doyle, 1987). To approximately 2-3 square centimetres of fresh leaf tissue, one $\mathrm{ml}$ of preheated $\left(68^{\circ} \mathrm{C}\right) \mathrm{CTAB}$ extraction buffer $[2 \%(\mathrm{w} / \mathrm{v}) \mathrm{CTAB}$, cetyltriammonium bromide (Sigma), $1.4 \mathrm{NaCl}, 20 \mathrm{mM}$ EDTA, 100mM Tris- $\mathrm{HCl}$ (pH 8.0), $0.2 \%$ 2-mercaptoethanol] was added and well homogenized with a mortar and pestle and transferred to a $2 \mathrm{ml}$ tube. Samples were incubated for $1.5 \mathrm{~h}$ at $68^{\circ} \mathrm{C}$ in a water bath. After incubation, $600 \mu \mathrm{l}$ of chloroform: isoamyl alcohol in a 24:1 proportion were added, and the samples were thoroughly mixed. The mixtures were centrifuged at $11.000 \mathrm{rev}$./ min for $10 \mathrm{~min}$. After centrifugation, the supernatant was transferred to a fresh $1.5 \mathrm{ml}$ tube and the DNA was precipitated by the addition of 0.1 vol. of $3 \mathrm{M}$ sodium acetate and 1 vol. of ice cold isopropanol and kept at $-20{ }^{\circ} \mathrm{C}$ for $30 \mathrm{~min}$. Samples were again centrifuged at 11.000 $\mathrm{rev} . / \mathrm{min}$ for $10 \mathrm{~min}$. The pellet was washed in $70 \%$ ethanol for $20 \mathrm{~min}$, air dried and rehydrated in $100 \mu \mathrm{l}$ of TE buffer (10 mM Tris- $\mathrm{HCl}, 1 \mathrm{mM}$ EDTA, $\mathrm{pH}$ 8.0). The DNA concentration was estimated by DNA fluorometer (Hoefer, TKO 100). Two replicate extractions per sample were performed.

\section{Microsatellites}

Six microsatellite loci (Table 2) developed earlier by Clarke and Tobutt (2006) were used: EMSn002, EMSn003, EMSn010, EMSn019, EMSn023 and EMSn025. Ten $\mu$ l of PCR mixture contained 2 ng DNA $(0.5 \mu \mathrm{l}), 5 \mu \mathrm{l}$ Qiagen Master Mix Kit, 0.5 $\mu \mathrm{l}$ of each primer (forward and reverse), $2 \mu_{\mathrm{l} \mathrm{H}} \mathrm{O}$ and $1.5 \mu \mathrm{lQ}$ solution. PCR condition consisted of an initial denaturation at $95{ }^{\circ} \mathrm{C}$ for $5 \mathrm{~min}$, followed by 30 cycles of $94{ }^{\circ} \mathrm{C}$ for $30 \mathrm{~s}$, $\mathrm{Ta}$ (different annealing temperatures for different loci) for 60 $\mathrm{s}$, and $72{ }^{\circ} \mathrm{C}$ for $60 \mathrm{~s}$, and a final step $10 \mathrm{~min}$ at $72{ }^{\circ} \mathrm{C}$. The annealing temperatures were different for the loci EMSn019, EMSn002, EMSn003 $\left(\mathrm{Ta}=60^{\circ} \mathrm{C}\right), \mathrm{EMSn} 010\left(\mathrm{Ta}=59^{\circ} \mathrm{C}\right)$ and EMSn023, EMSn025 $\left(\mathrm{Ta}=58{ }^{\circ} \mathrm{C}\right)$. The polymerase chain 
reaction (PCR) was performed using a Whatman Biometra T-Gradient thermocycler (Goettingen, Germany). Capillary electrophoresis of PCR products was performed on Beckman Coulter CEQ8000 according to manufacturer's instructions. Fragment size analysis was done with the in-build software. A fluorescent-labeled size marker (Beckman Coulter DNA Size Standard Kit 400 bp) was used as a molecular weight reference.

\section{Data analysis}

All unambiguous fragments were scored for the presence (1) or absence (0) of each band. Only clear and reproducible fragments were taken for data analysis. The binary data matrix was used to calculate Dice's similarity coefficients (Dice, 1945). Values of Dice's coefficients are between 0 (there is no common band) and 1 (two genotypes have identical markers, so they are identical). Dice similarity coefficients were calculated using the DARWIN computer package (Perrier and Jacquemond-Collet, 2006). For each microsatellite locus, the number of alleles per locus $(n)$, allele frequencies, observed heterozygosity $\left(H_{O}\right)$, expected heterozygosity $\left(H_{E}\right)$ and polymorphic information content (PIC) were calculated using the Cervus 3.0.7 computer program (Marshall et al., 1998; 2014 version). The average distance between pairs of accessions was obtained by taking into account microsatellite data and a neighbor-joining tree was constructed using the DARWIN computer package (Perrier and JacquemondCollet, 2006). A matrix of Dice similarity coefficients was used for assessing relationships among 47 genotypes using the neighbour-joining algorithm developed by Saitou and Nei (1987).

Table 1: Plant material included in molecular analysis

\begin{tabular}{|c|c|c|}
\hline $\begin{array}{l}\text { Sample } \\
\text { No. }\end{array}$ & Plant Material & Abbreviation \\
\hline 131 & S. racemosa & RAC \\
\hline 132 & S. nigra 1 & NI 1 \\
\hline 133 & S. miquelii & MIQ \\
\hline 134 & S. javanica 1 & JA 1 \\
\hline 136 & S. nigra 2 & NI 2 \\
\hline 137 & S. cerulea & CER \\
\hline 138 & S. tigranii & TIG \\
\hline 139 & S. koreana & KOR \\
\hline 140 & S. nigra 3 & NI 3 \\
\hline 141 & c.v. Black Beauty & $\mathrm{BB}$ \\
\hline 142 & $\mathrm{JA} \times \mathrm{EB} 9$ & JAEB 9 \\
\hline 143 & $\mathrm{JA} \times \mathrm{EB} 10$ & JAEB 10 \\
\hline 144 & $(\mathrm{JA} \times \mathrm{NI}) \times \mathrm{VIR}$ & JANI/VIR \\
\hline 145 & $\mathrm{JA} \times \mathrm{VIR}$ & JAVIR \\
\hline 146 & $(\mathrm{JA} \times \mathrm{CER}) \times(\mathrm{MIQ}+\mathrm{TIG})^{\mathrm{a}}$ & JACER/(MIQ+TIG) \\
\hline 147 & $\mathrm{JA} \times$ MIQ 1 & JAMIQ 1 \\
\hline 148 & $\mathrm{JA} \times \mathrm{TIG}$ & JATIG \\
\hline 150 & $(\mathrm{JA} \times \mathrm{NI}) \times(\mathrm{RAC}+\mathrm{TIG}) 1$ & JANI/(RAC+TIG) 1 \\
\hline 152 & $(\mathrm{JA} \times \mathrm{NI}) \times \mathrm{BB} 3$ & JANI/BB 3 \\
\hline 153 & $\mathrm{JA} \times \mathrm{CER}$ & JACER \\
\hline
\end{tabular}

\begin{tabular}{|c|c|c|}
\hline 155 & $(\mathrm{JA} \times \mathrm{NI}) \times(\mathrm{CER}+\mathrm{MIQ})$ & JANI/(CER+MIQ) \\
\hline 156 & $(\mathrm{JA} \times \mathrm{NI}) \times(\mathrm{RAC}+\mathrm{TIG}) 2$ & JANI/(RAC+TIG) 2 \\
\hline 157 & $\mathrm{JA} \times$ MIQ 2 & JAMIQ 2 \\
\hline 158 & $(\mathrm{JA} \times \mathrm{NI}) \times \mathrm{MIQ}$ & JANI/MIQ \\
\hline 162 & $\mathrm{JA} \times$ MIQ 3 & JAMIQ 3 \\
\hline 165 & S. javanica 2 & JA 2 \\
\hline 166 & Hybrid 5 & Hyb 5 \\
\hline 167 & Hybrid 3 & Hyb 3 \\
\hline 168 & S. nigra var. laciniata & LAC \\
\hline 170 & Hybrid 8 & Hyb 8 \\
\hline 171 & Hybrid 4 & Hyb 4 \\
\hline 172 & $\mathrm{NI}(\mathrm{Bg})$ & $\mathrm{NI}(\mathrm{Bg})$ \\
\hline 173 & Hybrid 2 & Hyb 2 \\
\hline 174 & Hybrid 6 & Hyb 6 \\
\hline 175 & Hybrid 7 & Hyb 7 \\
\hline 176 & Hybrid 1 & Hyb 1 \\
\hline 177 & Hybrid 9 & Hyb 9 \\
\hline 179 & S. ebulus 2 & EB 2 \\
\hline 180 & S. javanica 3 & JA 3 \\
\hline 182 & $\mathrm{JA} \times \mathrm{EB} 7$ & JAEB 7 \\
\hline 183 & $\mathrm{JA} \times(\mathrm{JA} \times \mathrm{EB}) 1$ & JA/JAEB 1 \\
\hline 184 & $\mathrm{JA} \times(\mathrm{JA} \times \mathrm{EB}) 2$ & JA/JAEB 2 \\
\hline 186 & $\mathrm{JA} \times(\mathrm{JA} \times \mathrm{EB}) 4$ & JA/JAEB 4 \\
\hline 187 & $\mathrm{JA} \times(\mathrm{JA} \times \mathrm{EB}) 5$ & JA/JAEB 5 \\
\hline 194 & JA $\times$ CER No. 3 & JACER No. 3 \\
\hline 195 & $(\mathrm{JA} \times \mathrm{NI}) \times \mathrm{CER}$ & JANI/CER \\
\hline 197 & S. sibirica & SIB \\
\hline
\end{tabular}

Note: a $-(\mathrm{JA} \times \mathrm{CER}) \times(\mathrm{MIQ}+\mathrm{TIG})$ means $($ S. javanica $\times$ S. cerulea $) \times($ S. racemosa-miquelii + S. racemosa - tigranii); + is indicating pollination with a mixture of pollen of 'MIQ' and 'TIG'. The names S. nigra (NI), S. cerulea (CER) and S. racemosa (RAC) correspond to the names $S$. nigra subsp. nigra, $S$. nigra subsp. cerulea and $S$. racemosa subsp. racemosa, respectively, according to the revised classification of Bolli (1994). S. racemosa subsp. racemosa also includes the taxa named as "miquelii" (MIQ), "sibirica" (SIB) and "tigranii" (TIG). The taxon "koreana" (KOR) is included in S. racemosa subsp. kamtschatica. S. javanica (JA) was represented by 3 genotypes. BB = S. nigra 'Black Beauty'; LAC $=S$. nigra subsp. nigra var. laciniata; $\mathrm{VIR}=S$. nigra subsp. nigra var. viridis; $\mathrm{Bg}=$ plants growing in the Maribor University Botanical Garden; Hyb = interspecific hybrids having partly known or unknown parental species.

\section{RESULTS AND DISCUSSION}

The number of alleles (Table 2) detected per locus ranged from 11 (EMSn025) to 18 (EMSn010, EMSn019), with an average of 15.17 alleles per locus. The observed heterozygosity ranged between 0.511 (locus EMSn023) and 0.787 (locus EMSn010), with an average of 0.656. The expected heterozygosity ranged between 0.791 (locus EMSn023) and 0.901 (locus EMSn003), with an average of 0.850. The differences between the observed and expected heterozygosity were observed on all loci. The largest difference was observed on locus EMSn003 (0.284) and the lowest on locus EMSn010 (0.084). The number of microsatellite markers sufficient for reliable variety identification depends on the nature and discriminating power of each marker (Tessier et al., 1999), normally six markers are sufficient for differentiating between genotypes (Zulini et al., 2002). 
Table 2. SSR loci analyzed and parameters of genetic variability calculated for different microsatellite loci of the 47 Sambucus genotypes: number of alleles $(n)$, effective number of alleles $\left(n_{e}\right)$, observed $\left(H_{o}\right)$ and expected $\left(H_{e}\right)$ heterozygosity, and polymorphic information content (PIC)

\begin{tabular}{|l|c|c|c|c|c|}
\hline Locus & $\mathbf{n}$ & $\mathbf{n}_{\mathrm{e}}$ & $\mathbf{H}_{\mathbf{o}}$ & $\mathbf{H}_{\mathrm{e}}$ & $\mathbf{P I C}$ \\
\hline EMSn002 & 15 & 8.87 & 0.702 & 0.838 & 0.809 \\
\hline EMSn003 & 16 & 9.22 & 0.617 & 0.901 & 0.882 \\
\hline EMSn010 & 18 & 7.21 & 0.787 & 0.871 & 0.850 \\
\hline EMSn019 & 18 & 9.00 & 0.745 & 0.898 & 0.880 \\
\hline EMSn023 & 13 & 4.60 & 0.511 & 0.791 & 0.758 \\
\hline EMSn025 & 11 & 4.86 & 0.574 & 0.803 & 0.774 \\
\hline Average & $\mathbf{1 5 . 1 6 7}$ & $\mathbf{6 . 7 9}$ & $\mathbf{0 . 6 5 6}$ & $\mathbf{0 . 8 5 0}$ & $\mathbf{0 . 8 2 5}$ \\
\hline
\end{tabular}

The reliability of microsatellite markers in genotyping of varieties was determined on the basis of the following criteria: the complexity of the banding pattern, the amplification of quality PCR products, the stability of the microsatellite repeated structure, and the polymorphic information content of markers. On the basis of PIC values, all the microsatellite loci were classified as very informative loci (PIC > 0.5), and all loci proved suitable for mapping (PIC > 0.7).

The allele sizes, frequencies and variability parameters calculated for each locus are shown in Table 3.

Table 3. Allele size (bp) and allele frequencies (in parenthesis) of the 47 Sambucus genotypes. at six microsatellite loci

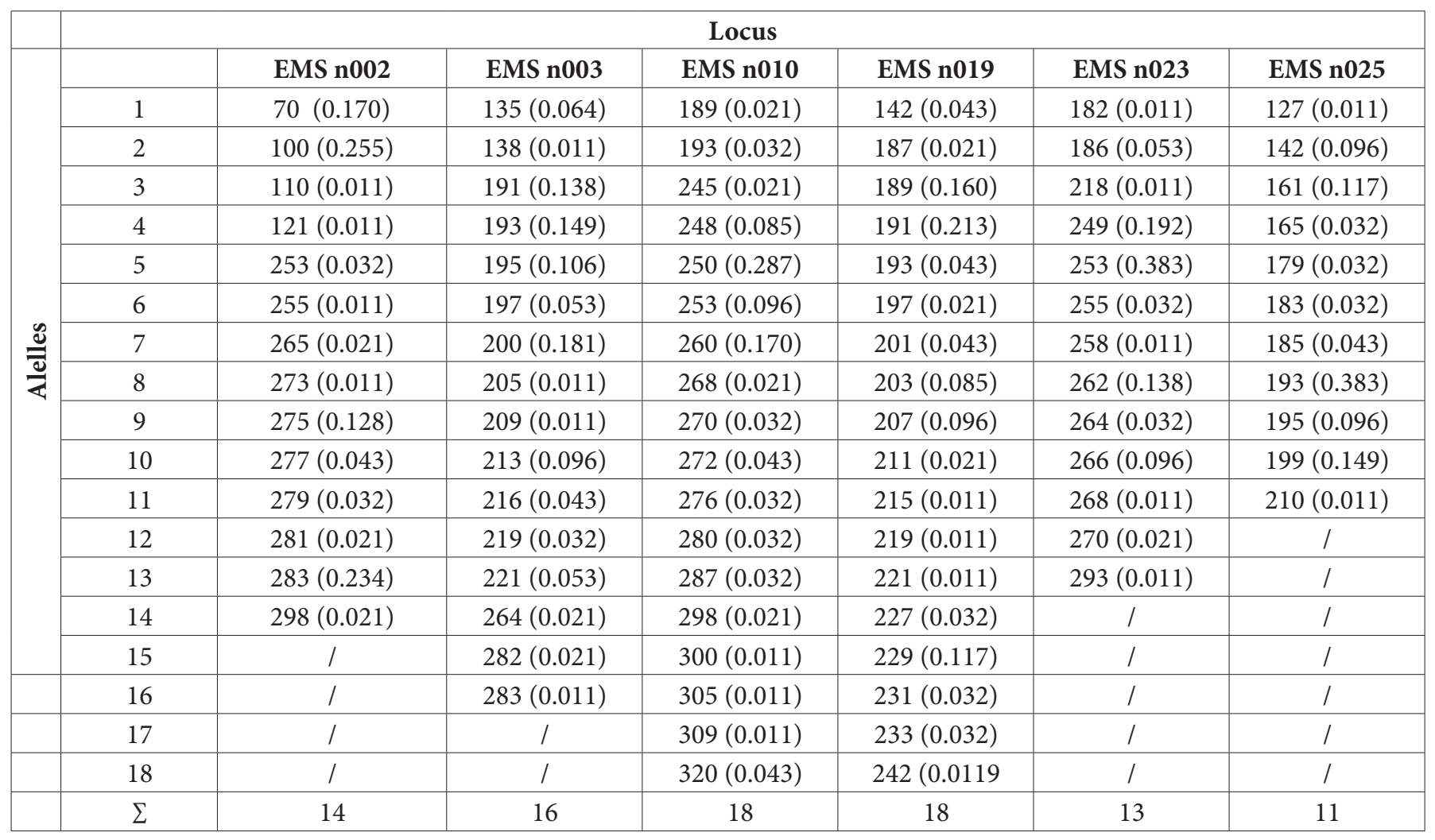

The molecular analysis indicates that the dendrogram (Fig. 1) encompasses four main groups of genotypes. The first main group involves two sub-groups. The first sub-group includes five taxons which, according to Bolli (1994), belong to S. racemosa (i.e.S. koreana (KOR), S. miquelii (MIQ), S. racemosa (in narrow sense - RAC), S. sibirica (SIB) and S. tigranii (TIG)), and three interspecific hybrids. The interspecific hybrid JANI/(CER+MIQ) (the accession 155), which is the result of pollination with a mixture of CER and MIQ pollen, is obviously JANI/MIQ. For the hybrid JACER/(MIQ+TIG)) (the accession 146), it is not possible to find out which of the parents (MIQ or TIG) participated in fertilisation. Following Bolli (1994), we can write JACER/RAC (meaning RAC in a broad sense). The second sub-group involves LAC (S. nigra subsp. nigra var. laciniata), two undetermined hybrids (most probably JANI/LAC or JALAC, and two hybrids involving VIR (S. nigra subsp. nigra var. viridis) - JAVIR and JANI/ VIR. In the second main group (Fig. 1), there are two subgroups. The first one involves NI 1 and its three hybrids, most probably with one of the S. javanica genotypes. Considering the background of these two hybrids (they originate from the first two cycles) of crosses, their parental structure is 


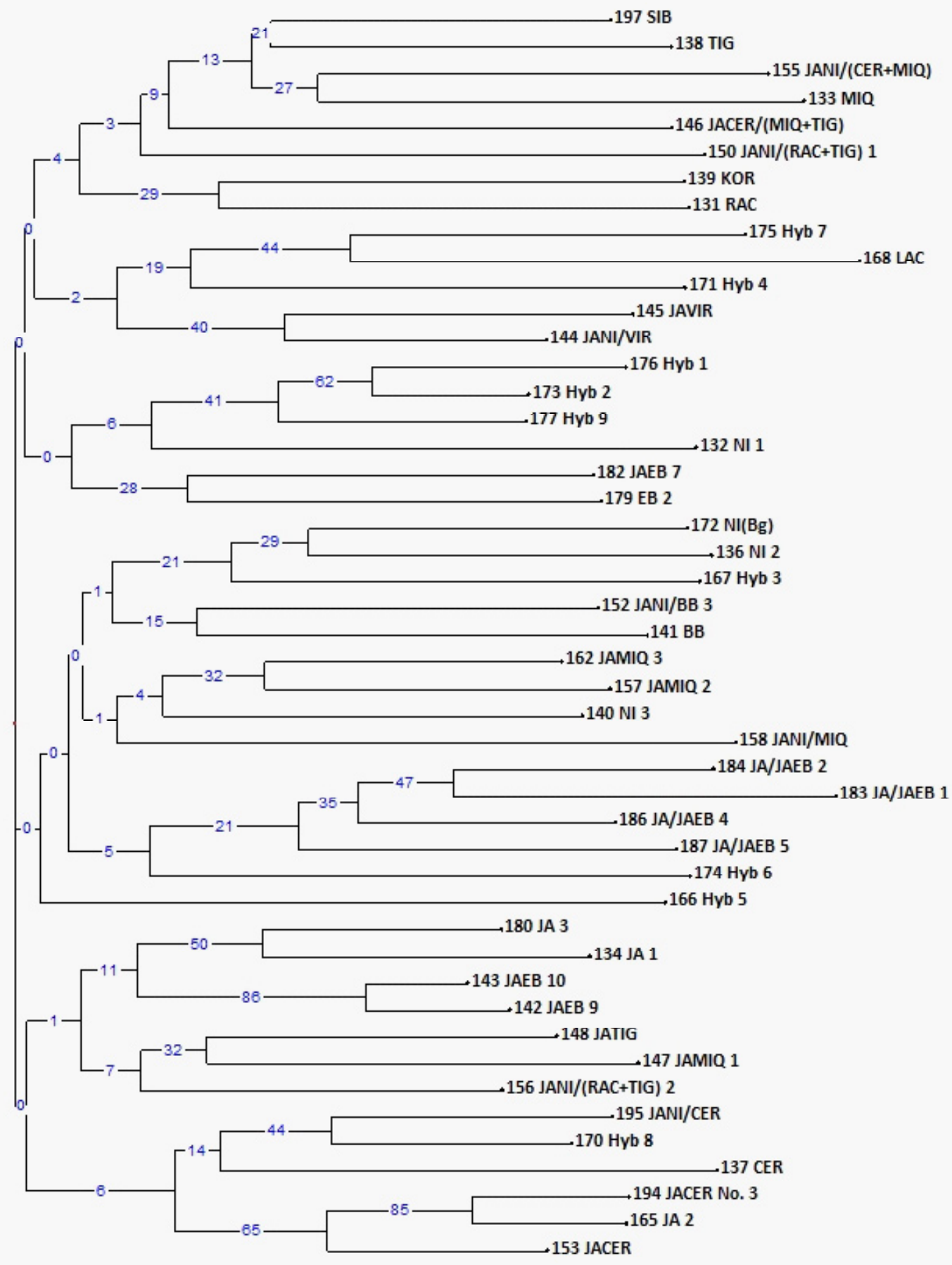

Figure 1: NJ dendrogram describing genetic relationships among 47 Sambucus genotypes based on SSR markers

probably JANI or JANI/NI. The second sub-group includes only two genotypes; one accession of S. ebulus and its hybrid with one of the genotypes of S. javanica (most probably the same JA genotype as in the first sub-group) - JAEB. The third main group contains three sub-groups and one hybrid (the accession 166 - Hyb 5) of which parents remain unknown. The first sub-group encompasses three $S$. nigra genotypes (NI $\mathrm{Bg}, \mathrm{NI} 2, \mathrm{BB})$, the accession JANI/BB 3 and undetermined Hyb 3 (the accession 167). This vigorous hybrid was probably JANI/NI, involving two different $S$. nigra genotypes. If it was JANI, the plants would be shorter because the genetic influence of (smaller) S. javanica parent would be stronger. The second sub-group includes two JAMIQ, one JANI/ MIQ and S. nigra genotype NI 3. This special accession of
NI is probably the reason that the two JAMIQ and JANI/ MIQ hybrids are not included in the first main group. The third sub-group includes backcrosses JA/JAEB. The $F_{1}$ hybrids originating from crosses $S$. javanica $\times$ S. ebulus were female sterile, however, they produced some fertile pollen and therefore it was possible to use them as male parental components. The resulting hybrids (JA/JAEB) were partly fertile and morphologically very attractive. The accession 174 (Hyb 6) is most probably JA/JAEB because hybrids resulting from further crosses involving this genotype were, at the time of sampling, not available.

The fourth main group includes three sub-groups. The first contains two accessions of S. javanica, both from Vanuatu, and two $F_{1}$ hybrids with S. ebulus - JAEB. The second sub-group 
includes three hybrids: JATIG, JAMIQ 1 and the accession 156 - JANI/(RAC + TIG). As we applied the mixture of $S$. racemosa (in narrow sense) and $S$. tigranii pollen, it is not possible to conclude which of these two taxons participated in the fertilisation. Following the sytematics of Bolli (1994), S. racemosa (in broad sense) encompasses also the taxon $S$. tigranii and therefore the hybrid structure should be JANI/ RAC. The third sub-group includes two main parental species (S. cerulea and one of the S. javanica genotypes), $\mathrm{F}_{1}$ hybrids between S. javanica and S. cerulea, and two 'threespecies' hybrids between $\mathrm{F}_{1}$ progenies $S$. javanica $\times$ S. nigra and S. cerulea (the undetermined hybrid 170 (Hyb 8) is most probably JANI/CER).

The positions of main groups, sub-groups and individual hybrids in the presented dendrogram (Fig. 1) depend on several factors: (a) accuracy of crosses, including labelling, (b) accuracy of molecular analysis, (c) genetic structure of individual parents, (d) their contribution of nuclear genes to the final hybrid structure (e.g., S. nigra in JANI/MIQ contributes $25 \%$ of nuclear genes while in JANI/NI $75 \%$ ), (e) complexity of a particular interspecific hybrid (e.g. JAEB vs. JA/JAEB) and (f) genetic uniformity of parental species which are used two or more times in forming a hybrid (e.g., JANI/NI was formed in two steps $-\mathrm{F}_{1}$ (JANI) in the first year, while JANI/NI two, three or even four years later - usually involving another (completely different) S. nigra genotype).

The accuracy is probably the biggest problem in elderberry crosses due to sensitivity and small size of flowers distributed in relatively very dense inflorescences. During the first two years of interspecific hybridisation, when using several plants/genotypes of a particular species (e.g., of S. nigra or S. ebulus), we documented all essential details about parental components. It was much easier when there was only one genotype of a particular parental species, as it was in the case of S. cerulea, S. koreana, S. miquelii, S. sibirica and S. racemosa in narrow sense (considering the classical systematics of the genus Sambucus). When conducting the first crosses, we also documented the use of substances promoting pollen germination (i.e., different although very low concentrations of honey or sugar) which were used in more than $90 \%$ of successful crosses. In later generations, the number of crosses increased and they became more complex. The labels became too small and we could document only the date of hybridisation, the chemical treatment of stigma (if any) and abbreviations of the parents (NI, EB, JA. etc.). Another problem arising in later cycles of the recurrent selection, when the programme intensified, was a need to extend crossings over a longer period (i.e., from mid-May to the beginning of October). Consequently, we had to look for late and very late flowering parental species. Late flowering $S$. ebulus and S. nigra could be found only in shade, on higher altitudes (in our case between 800 and $900 \mathrm{~m}$ asl.). Interspecific hybrids were generally characterised by late flowering, and more than half of crosses were conducted in the third decade of August and in September.

Our study shows that molecular analysis can be very helpful in determining some of the unknown interspecific hybrid structures. However, when using different genotypes of the involved parental species, it is very important to record their details. Interspecific hybrids involving only two species should not cause serious problems, as it was demonstrated by Simonovik et al. (2007). The putative interspecific hybrid structure of $\mathrm{F}_{1}$ hybrids can also be checked phenotypically. In most cases, the comparison of offspring plants with their parental species (especially the female parent) appears to be sufficient to confirm their hybrid nature. The situation, however, can become completely unclear in the case of complex hybrids. One of the examples was already mentioned in Introduction: $((S$. javanica $\times S$. cerulea $) \times($ S. javanica $\times S$. racemosa $)) \times(($ S. cerulea $\times$ S. nigra $) \times($ S. javanica $\times S$. nigra $)$. Such a complex hybrid structure involving four different species probably cannot be resoved neither by molecular nor by morphological approaches.

\section{CONCLUSION}

The phenotypic and genotypic variations within the genus Sambucus are very limited, especially when considering the traits associated with fruits and inflorescences. The most efficient way to increase the variation is most probably the genetic recombination involving different species. Interspecific hybridisation of elderberries, at the Faculty of Agriculture and Life Sciences, University of Maribor, Slovenia, has a relatively long tradition. It began in 2003, although the first experimental crosses based on normal hand emasculation technique took place several years before. The work became more productive when a self-incompatible genotype of $S$. javanica was introduced from the Island of Espiritu Santo, Vanuatu. Due to almost complete selfincompatibility, emasculation of the female parent was not necessary. The result were numerous hybrids, involving two, three or four elderberry species. The aim of the presented investigation was to assess the possibility of using molecular approach (i.e., microsatellites) in determination of unknown hybrid structures. Samples of analysed hybrids were collected in May 2016 and DNA was extracted from fresh, young leaves. The molecular analysis indicated that the dendrogram consisted of four main groups of genotypes. The first main group involved two sub-groups: one including five taxons belonging to $S$. racemosa (in broad sense), and the other involving S. nigra subsp. nigra var. laciniata and S. nigra subsp. nigra var. viridis. In the second main group, there was a sub-group involning hybrids between $S$. javanica and $S$. nigra, and a sub-group involving hybrids between $S$. javanica and S. ebulus. The third main group contained a sub-group with hybrids between S. javanica and S. nigra 'Black Beauty', a sub-group involving hybrids with $S$. javanica, $S$. nigra and $S$. racemosa (miquelii), a sub-group with backcrosses $S$. javanica $\times(S$. javanica $\times S$. ebulus $)$, and un unknown hybrid. The fourth main group included a sub-group with $\mathrm{F}_{1}$ hybrids $S$. javanica $\times S$. ebulus, a sub-group involving various taxons of $S$. racemosa (in broad sense), and a sub-group involving hybrids between S. cerulea and S. javanica, with or without S. nigra. Our study shows that molecuar analysis can be very helpful in determining some of the unknown, but not complex interspecific hybrid structures. In the cases of complex interspecific hybrid combinations (e.g., complex backcrosses, hybrids involving three or more species, convergent or successive crosses), SSRs were most probably insufficient for the determination the exact hybrid structure. 


\section{REFERENCES}

1. Applequist, W. L. (2015). A brief review of recent controversies in the taxonomy and nomenclature of Sambucus nigra sensu lato. Acta Horticulturae, 1061, 25-33. Retrieved from: https://doi: 10.17660/ ActaHortic.2015.1061.1

2. Atkinson, M. D., \& Atkinson, E. (2002). Sambucus nigra L. - Biological flora of the British Isles. No. 225. Journal of Ecology, 90, 895-923.

3. Böcher, T. W. (1941). Højsommerekskursionen til Brædstrup. Bryrup og Vrads. Botanisk Tidsskrift, 45, 433-439.

4. Bolli, R. (1994). Dissertationes Botanicae Band 223. Revision of the Genus Sambucus. J. Cramer, Berlin, Stuttgart.

5. Charlebois, D., Byers, P. L., Finn, C. E., \& Thomas, A. L. (2010). Elderberry: botany, horticulture, potential. Horticultural Reviews, 37, 213-280.

6. Chia, C. L. (1975). A chromosome and thin-layer chromatographic study of the genus Sambucus L. (Doctoral dissertation). Cornell University. College of Agriculture and Life Sciences. Department of Plant Biology. New York. 50 pp.

7. Clarke, J. B., \& Tobutt, K. R. (2006). Development of microsatellite primers and two multiplex polymerase chain reactions for the common elder (Sambucus nigra). Molecular Ecology Notes, 6, 453-455.

8. Dice, L. R. (1945). Measures of the amount of ecologic association between species. Ecology, 26, 297-302.

9. Doyle, J. J., \& Doyle, J. L. (1987). A rapid DNA isolation procedure for small quantities of fresh leaf tissue. Phytochemical Bulletin,19, 11-15.

10. Fernald, M. L. (1950). Gray's manual of botany, 8th ed. New York, NY: American Book Company.

11. Imenšek, N., Kristl, J., Sem, V., \& Ivančič, A. (2020). Elderberry (Sambucus spp.) interspecific hybridization and its impact on fruit oxalates. Plant Breeding, 139(2). Retrieved from: https://onlinelibrary.wiley.com/doi/ full/10.1111/pbr.12808

12. Koncalová, M. N., Hrib, J., \& Jicínská, D. (1983). The embryology of the Sambucus species and hybrids. In Fertilization and Embryogenesis in Ovulated Plants. Proceedings of the VII International Cytoembryological Symposium; Erdelská. O. Ed.; August 1982, Bratislava, Czechoslovakia, 43-47.

13. Marshall, T. C., Slate, J., Kruuk, L. E. B., \& Pemberton, J. M. (1998). Statistical confidence for likelihood-based paternity inference in natural populations. Molecular Ecology Notes, 7, 639-655.

14. Mikulič-Petkovšek, M., Ivančič, A., Schmitzer, V., Veberič, R., \& Štampar, F. (2016). Comparison of major taste compounds and antioxidative properties of fruits and flowers of different Sambucus species and interspecific hybrids. Food Chemistry, 200, 134-140.

15. Mikulič-Petkovšek, M., Ivančič, A., Todorović, B., Veberič, R., \& Štampar, F. (2015a). Fruit phenolic composition of different elderberry species and hybrids. Journal of Food Science, 80, C2180-C2190.

16. Mikulič-Petkovšek, M., Samoticha, J., Eler, K., Štampar,
F., \& Veberič, R. (2015b). Traditional elderflower beverages: a rich source of phenolic compounds with high antioxidant activity. Journal of Agricultural and Food Chemistry, 63, 1477-1487.

17. Mikulič-Petkovšek, M., Schmitzer, V., Slatnar, A., Todorović, B., Veberič, R., Štampar, F., \& Ivančič, A. (2014). Investigation of anthocyanin profile of four elderberry species and interspecific hybrids. Journal of Agricultural and Food Chemistry, 62(24), 5573-5580.

18. Nilsson, A. (1987). Hybriden mellan fläder och druvfläder funnen i Skåne. Svensk Botanisk Tidskrift, 81, 174-175.

19. Perrier, X., \& Jacquemoud-Collet, J. P. (2006). DARwin software. Retrieved from: http://darwin.cirad.fr/ darwin.

20. Saitou, N., \& Nei, M. (1987). The neighbor-joining method: A new method for reconstructing phylogenetic trees. Molecular Biology Evolution, 4, 406-425.

21. Shokrzadeh, M., \& Saravi, S. S. S. (2010). The chemistry, pharmacology and clinical properties of Sambucus ebulus: a review. Journal of Medicinal Plants Research, 4, 95-103

22. Simonovik, B. (2007). Genetic evaluation of interspecific hybrids in the genus Sambucus and establishment of selected plant tissue culture techniques in common elder (S. nigra L.) (Doctoral dissertation). Biotechnical Faculty, University of Ljubljana, Ljubljana.

23. Simonovik, B., Ivančič, A., Jakše, J., \& Bohanec, B. (2007). Production and genetic evaluation of interspecific hybrids within the genus Sambucus. Plant Breeding, 126(6), 628-633.

24. Tessier, C., David, J., This, P., Boursiquot, J. M., \& Charrier, A. (1999). Optimization of the choice of molecular markers for varietal identification in Vitis vinifera L. Theoretical and Applied Genetics, 98, 171177.

25. Todorović, B., Mikulič-Petkovšek, M., Štampar, F., \& Ivančič, A. (2017). Phenolic compounds in floral infusions of various Sambucus species and their interspecific hybrids. Turkish Journal of Agriculture and Forestry, 41(2), 154-164.

26. Vlachojannis, J. E., Cameron, M., \& Chrubasik, S. (2010). A systematic review on the sambuci fructus effect and efficacy profiles. Phytotherapy Research, 24(1), 1-8.

27. von Linné, C. (Caroli Linnaei). 1753. Species plantarum: exhibentes plantas rite cognitas, ad genera relatas, cum differentiis specificis, nominibus trivialibus, synonymis selectis, locis natalibus, secundum systema sexuale digestas... Holmiae; Impensis Laurentii Salvii. Retrieved from: https://doi.org/10.5962/bhl.title.669

28. von Schwerin, F. G. (1920). Revisio generis Sambucus. Mitteilungen der Deutschen dendrologischen gesellschaft, 29, 194-231.

29. Wenga, J. -R., Linb, C. -S., Laic, H. -C., Line, Y. -P., Wange, C. -Y., Tsaie, Y.-C., Wuf, K. -C., Huangg, S. -H., \& Line, C. -W. (2019). Antiviral activity of Sambucus Formosana Nakai ethanol extract and related phenolic acid constituents against human coronavirus NL63. Virus Research, 273, 1-8.

30. Weston, R. (1775). The English flora: or, a catalogue of 
trees, shrubs, plants and fruits, natives as well as exotics, cultivated, for use or ornament, in the English nurseries, greenhouses and stoves: arranged according to the Linnaean system: with the Latin trivial, and common English names, and an English index referring to the Latin names. Also a general catalogue of seeds for the kitchen-garden, flower-garden, grass-lands etc., usually raised for sale, and those annually imported from America. Printed for the Author and sold by: Millan, J., Robson and Co. New Bond-Street, Carnan, T., St. Paul's Church-Yard, Dilly, E., and C., London.

31. Winge, Ö. (1944). The Sambucus hybrid S. nigra $\times$ S. racemosa. Comptesrendus des travaux du laboratoire Carlsberg. Sér Physiolog, 24, 73-78.

32. Zulini, L., Russo, M., \& Peterlunger, E. (2002). Genotyping wine and table grape cultivars from Apulia (Southern Italy) using microsatellite markers. Vitis, 41, 183-187. 


\section{Določitev strukture medvrstnih križancev iz rodu Sambucus z uporabo molekulskih markerjev}

\section{IZVLEČEK}

Fenotipska in genotipska raznolikost znotraj rodu Sambucus je sorazmerno zelo omejena. To raznolikost lahko učinkovito povečamo z medvrstnimi križanji. Namen raziskave je bil uporabiti molekulske markerje (mikrosatelite) za določanje strukture vzorčenih medvrstnih križancev bezga oz. določiti, katere vrste bezga so bile uporabljene pri oblikovanju posameznih medvrstnih križancev. V raziskavo je bilo vključenih 47 genotipov rodu Sambucus (starševske vrste in/ali medvrstni križanci) in uporabljeno je bilo šest mikrosatelitskih lokusov. Metoda združevanja je analizirane genotipe razvrstila v štiri glavne skupine. Prva glavna skupina je vključevala dve podskupini: eno s taksoni in križanci, ki vključujejo S. racemosa (v širšem smislu), druga pa je vključevala dve sorti S. nigra. V drugi glavni skupini je bila podskupina, v kateri so bili križanci med S. javanica in S. nigra, in podskupina, ki je vključevala $\mathrm{F}_{1}$ križance med S. javanica in S. ebulus. Tretja glavna skupina je obsegala podskupino s križanci med $S$. javanica in $S$. nigra 'Black Beauty', podskupino s križanci, ki vključujejo S. javanica, S. nigra in S. racemosa (miquelii), podskupino s povratnim križanjem $S$. javanica $\times($. javanica $\times$ S. ebulus $)$ in en nedoločljivi medvrstni križanec. Četrta glavna skupina je vključevala podskupino $\mathrm{z} \mathrm{F}_{1}$ križanci $S$. javanica $\times S$. ebulus, podskupino, ki vključuje različne taksone $S$. racemosa (v širšem smislu), in podskupino, ki vključuje križance med $S$. cerulea in $S$. javanica, z in brez $S$. nigra. Naša raziskava kaže, da je molekulska analiza lahko zelo koristna za določanje nekaterih neznanih, a strukturno enostavnih medvrstnih križancev iz rodu Sambucus. V primeru bolj zapletenih kombinacij medvrstnih križanj pa uporaba mikrosatelitov verjetno ni najboljša rešitev.

Ključne besede: Sambucus, mikrosatelitski markerji, medvrstni križanci, metoda razvrščanja v skupine, molekulski markerji 